\title{
molecules
}

ISSN 1420-3049

www.mdpi.com/journal/molecules

Article

\section{Naucline, a New Indole Alkaloid from the Bark of Nauclea officinalis ${ }^{\dagger}$}

Sook Yee Liew ${ }^{1}$, Mat Ropi Mukhtar ${ }^{1}$, A. Hamid A. Hadi ${ }^{1}$, Khalijah Awang ${ }^{1, *}$, Mohd Rais Mustafa ${ }^{2}$, Kazumasa Zaima ${ }^{3}$, Hiroshi Morita ${ }^{3}$ and Marc Litaudon ${ }^{4}$

1 Department of Chemistry, Faculty of Science, University of Malaya, 50603 Kuala Lumpur, Malaysia; E-Mails: joeyliew5382@um.edu.my (S.Y.L.); ahamid@um.edu.my (A.H.A.H.)

2 Department of Pharmacology, Faculty of Medicine, University of Malaya, 50603 Kuala Lumpur, Malaysia; E-Mail: rais@um.edu.my

3 Faculty of Pharmaceutical Sciences, Hoshi University, Shinagawa-ku, Tokyo 142-8501, Japan; E-Mail: moritah@hoshi.ac.jp

4 Institut de Chimie de la Substances Naturelles, Centre Nationale de la Recherches Scientifique, 91198, Gif-sur Yvette, Cedex, France; E-Mail: marc.litaudon@icsn.cnrs-gif.fr

$\dagger$ We wish to dedicate this article to our dearest colleague, Dr. Mat Ropi bin Mukhtar who has been a great inspiration to natural product research in Malaysia and globally.

* Author to whom correspondence should be addressed; E-Mail: khalijah@um.edu.my; Tel.: +603-7967-4064; Fax: +603-7967-4193.

Received: 9 February 2012; in revised form: 27 March 2012 / Accepted: 28 March 2012 / Published: 2 April 2012

\begin{abstract}
A new indole alkaloid, naucline (1) together with four known alkaloids, angustine (2), angustidine (3), nauclefine (4) and naucletine (5), were isolated from the bark of Nauclea officinalis. The structures of all isolated compounds were elucidated with various spectroscopic methods such as 1D- and 2D- NMR, IR, UV and LCMS-IT-TOF. In addition to that of alkaloid $\mathbf{1}$, the complete ${ }^{13} \mathrm{C}-\mathrm{NMR}$ data of naucletine (5) were also reported. Naucline (1) showed a moderate vasorelaxant activity $(90 \%$ relaxation at $1 \times 10^{-5} \mathrm{M}$ ) whereas, angustine (2), nauclefine (4), and naucletine (5) showed potent vasorelaxant activity (more than $90 \%$ relaxation at $1 \times 10^{-5} \mathrm{M}$ ) on an isolated rat aorta.
\end{abstract}

Keywords: naucline; angustine; angustidine; nauclefine; naucletine; Rubiaceae; vasorelaxant activity 


\section{Introduction}

The Rubiaceae family is known as Madder or Bedstraw, comprising 650 genera and 10,500 species worldwide [1]. Most of them are distributed primarily in the tropical regions and are mainly woody trees and shrubs [2]. A number of monoterpenoid indole alkaloids have been isolated from the Nauclea genus [3]. Some of these alkaloids were reported to exhibit certain biological activities such as anticonvulsant, antiproliferative, antimalarial, antimicrobial and antiparasitic properties [4-8]. Nauclea officinalis, a traditional Chinese medicine, is reported to contain alkaloids and terpenoids as major components $[9,10]$.

In our continuous effort of searching for interesting chemical constituents of the Rubiaceae family from Malaysia [11], a new monoterpenoid indole alkaloid has been isolated from the bark of Nauclea officinalis. In addition to the new compound, four known alkaloids, angustine (2) [12-18], angustidine (3) $[13,17,19]$, nauclefine (4) $[15,19-21]$ and naucletine (5) $[15,19,22]$ were also isolated (Figure 1). In the present paper, we report the isolation and characterization of this new indoloquinolizidinone alkaloid, namely naucline (1) and the vasorelaxant activity of the indole alkaloids 1, 2, 4 and $\mathbf{5}$. The ${ }^{13} \mathrm{C}-\mathrm{NMR}$ data of naucletine (5) are also presented.

Figure 1. Structures of naucline (1), angustine (2), angustidine (3), nauclefine (4), and naucletine (5).

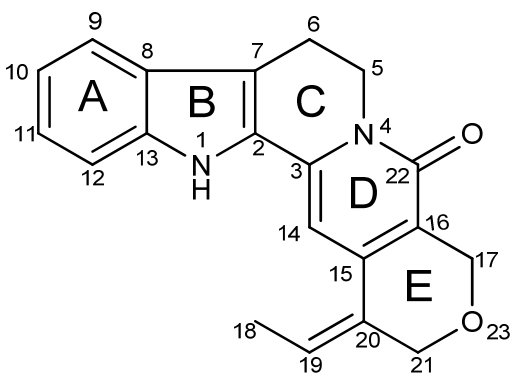

1<smiles>C=Cc1cncc2c(=O)n3c(cc12)-c1[nH]c2ccccc2c1CC3</smiles>

2<smiles>Cc1cc2cc3n(c(=O)c2cn1)CCc1c-3[nH]c2ccccc12</smiles>

3<smiles>O=c1c2cnccc2cc2n1CCc1c-2[nH]c2ccccc12</smiles>

4<smiles>CC(=O)c1cncc2c(=O)n3c(cc12)-c1[nH]c2ccccc2c1CC3</smiles>

5

\section{Results and Discussion}

Naucline (1) was isolated as a brownish amorphous solid. The LCMS-IT-TOF spectrum revealed a pseudomolecular ion peak $[\mathrm{M}+\mathrm{H}]^{+}$at $\mathrm{m} / \mathrm{z} 319.1450$, corresponding to the molecular formula of $\mathrm{C}_{20} \mathrm{H}_{18} \mathrm{~N}_{2} \mathrm{O}_{2}$. In the IR spectrum, an absorption band due to a conjugated carbonyl stretching vibration was observed at $1638 \mathrm{~cm}^{-1}$. 
In the ${ }^{1} \mathrm{H}-\mathrm{NMR}$ spectrum, the presence of four aromatic protons, a broad peak of -NH- and one $-\mathrm{CH}_{2}-\mathrm{CH}_{2}-\mathrm{N}$ - group were observed, suggesting a $\beta$-carboline skeleton [10]. Two of the four aromatic protons in ring $\mathrm{A}$ appeared as doublets at $\delta_{\mathrm{H}} 7.48$ and 7.33, and the other as two doublet of doublets (dd) at $\delta_{\mathrm{H}} 7.10$ and 7.21 were attributed to $\mathrm{H}-9, \mathrm{H}-12, \mathrm{H}-10$, and $\mathrm{H}-11$, respectively. $\mathrm{H}-14$ of ring $\mathrm{D}$ was revealed as a singlet at $\delta_{\mathrm{H}} 6.32$ indicating that a double bond could be formed between C-15 and C-16. In addition, two upfield signals of $\mathrm{H}-19\left(\delta_{\mathrm{H}} 5.76, \mathrm{q}, J=6.6 \mathrm{~Hz}\right)$ and methyl protons $\left(\delta_{\mathrm{H}} 1.46, \mathrm{~d}, J=6.6 \mathrm{~Hz}\right)$ characteristic of trisubstituted olefin group were observed [10]. The ${ }^{13} \mathrm{C}-\mathrm{NMR}$ and DEPT spectra of naucline (1) indicated a total of 20 carbon signals; one methyl, one carbonyl, four methylenes, six methines and eight quaternary carbons. The presence of a carbonyl carbon was observed at $\delta_{\mathrm{C}} 163.1$. The signals at $\delta_{\mathrm{C}} 58.9$ and 66.6 could be assigned as the resonances of two oxymethylenes, C-17 and C-21, respectively.

Selected 2D NMR correlations (COSY and HMBC) for naucline (1) are shown in Figure 2. Complete ${ }^{1} \mathrm{H}$ - and ${ }^{13} \mathrm{C}$-NMR (Table 1) spectral assignment of $\mathbf{1}$ was accomplished through analysis of COSY, HMQC, HMBC and NOESY data. The presence of a trisubstituted olefin with a methyl group at $\mathrm{C}-19\left(\delta_{\mathrm{C}} 119.5\right)$ and an oxymethylene at C-20 were determined by using HMBC correlations from $\mathrm{H}-14, \mathrm{H}-18\left(\delta_{\mathrm{H}} 1.46\right)$, and H-21 $\left(\delta_{\mathrm{H}} 4.18, \mathrm{~d}\right)$ to $\mathrm{C}-20\left(\delta_{\mathrm{C}} 148.0\right)$, and from H-18, H-19 $\left(\delta_{\mathrm{H}} 5.76\right)$ and $\mathrm{H}-21$ to $\mathrm{C}-15\left(\delta_{\mathrm{C}} 136.6\right)$ (Figure 2 ). The COSY spectrum showed correlation peaks between $\mathrm{H}_{2}-5 / \mathrm{H}_{2}-6$ and $\mathrm{H}_{3}-18 / \mathrm{H}-19$ respectively. NOESY correlations of naucline (1) is shown in Figure 3.

Figure 2. Selected 2D NMR correlations for naucline (1).
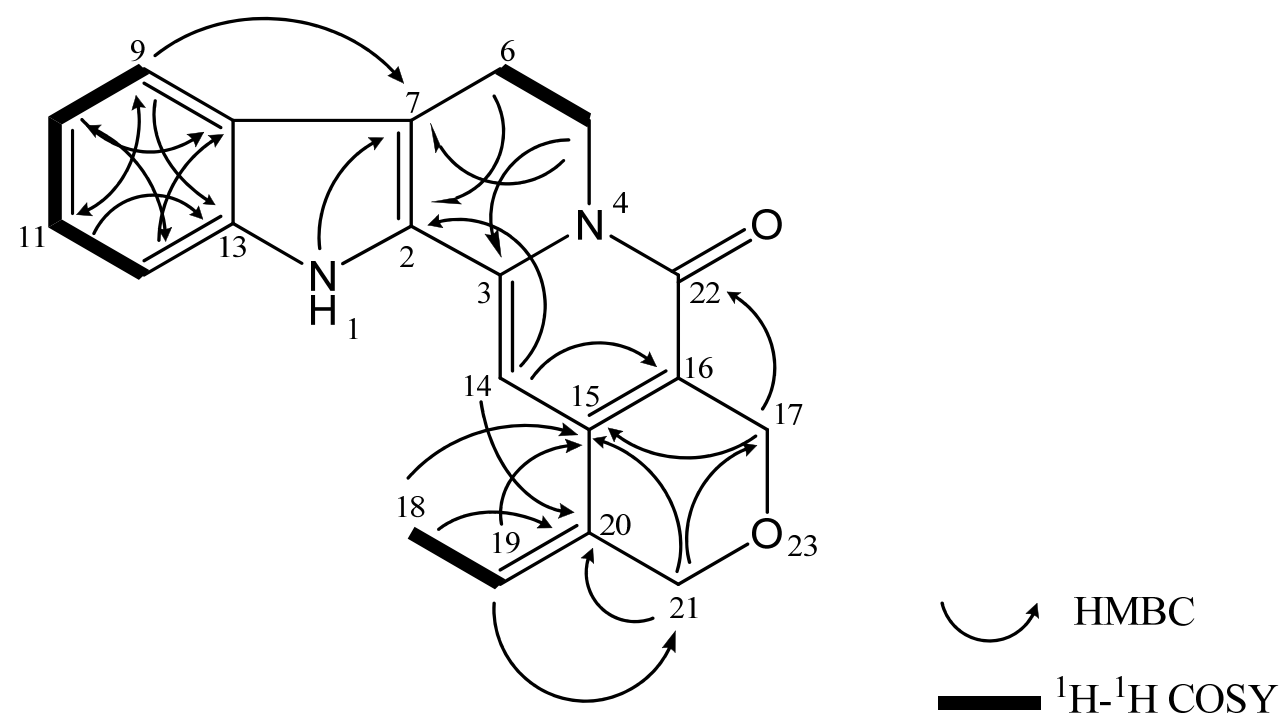

Four known alkaloids, angustine (2), angustidine (3), nauclefine (4), naucletine (5) were isolated as brownish amorphous solids. The LCMS-IT-TOF spectra showed molecular ion peaks, $[\mathrm{M}+\mathrm{H}]^{+}$at $\mathrm{m} / \mathrm{z}$ $314.1316\left[\mathrm{C}_{20} \mathrm{H}_{15} \mathrm{~N}_{3} \mathrm{O}\right], 302.1317\left[\mathrm{C}_{19} \mathrm{H}_{15} \mathrm{~N}_{3} \mathrm{O}\right], 288.1155\left[\mathrm{C}_{18} \mathrm{H}_{13} \mathrm{~N}_{3} \mathrm{O}\right]$, and $330.1309\left[\mathrm{C}_{20} \mathrm{H}_{15} \mathrm{~N}_{3} \mathrm{O}_{2}\right]$ respectively. The spectroscopic data of $\mathbf{5}$ were reported in comprehensive reviews [15,23], but its ${ }^{13} \mathrm{C}-\mathrm{NMR}$ data were lacking. In view of that, complete assignments were established through various NMR measurements; DEPT, HSQC, and HMBC spectra. The ${ }^{13} \mathrm{C}-\mathrm{NMR}$ spectra of naucletine (5) indicated the presence of 20 carbons. Two carbonyl carbons were observed at $\delta_{\mathrm{C}} 199.6\left(-\mathrm{CCOCH}_{3}\right)$ and 161.6 (-NCOC-), respectively. 
Table 1. ${ }^{1} \mathrm{H}-\mathrm{NMR}(400 \mathrm{MHz})$ and ${ }^{13} \mathrm{C}-\mathrm{NMR}(100 \mathrm{MHz})$ Spectral Data of Naucline (1) and Naucletine (5) in $\mathrm{CDCl}_{3}$.

\begin{tabular}{|c|c|c|c|c|}
\hline \multirow[t]{2}{*}{ Position } & \multicolumn{2}{|l|}{1} & \multicolumn{2}{|l|}{5} \\
\hline & ${ }^{1} \mathbf{H}\left(\delta_{H}, H z\right)$ & ${ }^{13} \mathrm{C}\left(\delta_{\mathrm{C}}\right)$ & ${ }^{1} \mathbf{H}\left(\delta_{\mathrm{H}}, \mathrm{DMSO}, \mathbf{H z}\right)^{\mathrm{a}}$ & ${ }^{13} \mathrm{C}\left(\delta_{\mathrm{C}}\right)$ \\
\hline NH-1 & $9.72(\mathrm{~s})$ & - & & \\
\hline 2 & - & 127.4 & - & 127.4 \\
\hline 3 & - & 137.9 & - & 140.8 \\
\hline $5 a$ & $4.03(\mathrm{~m})$ & 40.7 & $4.39(\mathrm{t}, 6.9)$ & 40.7 \\
\hline $5 b$ & $4.59(\mathrm{~m})$ & & & \\
\hline 6 & $2.96(\mathrm{~m})$ & 19.5 & $3.12(\mathrm{t}, 6.9)$ & 19.8 \\
\hline 7 & - & 114.4 & - & 116.9 \\
\hline 8 & - & 125.6 & - & 125.7 \\
\hline 9 & $7.48(\mathrm{~d}, 7.8)$ & 119.5 & $7.65(\mathrm{~d}, 8.0)$ & 119.3 \\
\hline 10 & $7.10(\mathrm{dd}, 7.8,7.3)$ & 120.5 & $7.07(\mathrm{~m})$ & 119.9 \\
\hline 11 & $7.21(\mathrm{dd}, 7.3,8.2)$ & 124.7 & $7.23(\mathrm{~m})$ & 120.9 \\
\hline 12 & $7.33(\mathrm{~d}, 8.2)$ & 111.9 & $7.45(\mathrm{~d}, 8.1)$ & 112.0 \\
\hline 13 & - & 138.5 & - & 139.0 \\
\hline 14 & $6.32(\mathrm{~s})$ & 102.0 & $7.73(\mathrm{~s})$ & 95.6 \\
\hline 15 & - & 136.6 & - & 141.1 \\
\hline 16 & - & 125.7 & - & 117.1 \\
\hline \multirow[t]{2}{*}{17} & $4.36(\mathrm{br} \mathrm{d}, 12.1)$ & 58.9 & $9.21(\mathrm{~s})$ & 154.0 \\
\hline & $4.65(\mathrm{br} \mathrm{d}, 12.1)$ & & & \\
\hline 18 & $1.46(\mathrm{~d}, 6.6)$ & 14.6 & $2.71(\mathrm{~s})$ & 29.3 \\
\hline 19 & $5.76(q, 6.6)$ & 125.9 & - & 199.6 \\
\hline 20 & - & 148.0 & - & 138.8 \\
\hline \multirow[t]{2}{*}{21} & $4.18($ br d, 11.9) & 66.6 & $9.41(\mathrm{~s})$ & 155.4 \\
\hline & $4.20($ br d, 11.9) & & & \\
\hline 22 & - & 163.1 & - & 161.6 \\
\hline
\end{tabular}

${ }^{\text {a } 1} \mathrm{H}-\mathrm{NMR}$ data are reported from Lavilla et al.

Figure 3. Selected NOESY correlations of naucline (1).

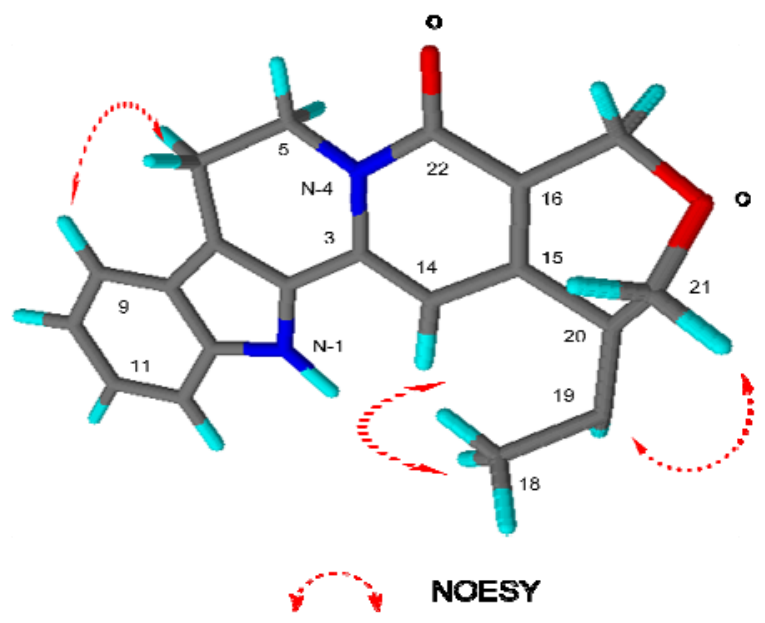


Vasodilators are useful for treatment of cerebral vasospasm and hypertension, and for improvement of peripheral circulation [24]. After phenylephrine (PE) $3 \times 10^{-7} \mathrm{M}$ was applied to thoracic aortic rings with endothelium and after achieving a maximal response, we added naucline $\left(1 ; 1 \times 10^{-5} \mathrm{M}\right)$, angustine $\left(2 ; 1 \times 10^{-5} \mathrm{M}\right)$, nauclefine $\left(4 ; 1 \times 10^{-5} \mathrm{M}\right)$, and naucletine $\left(5 ; 1 \times 10^{-5} \mathrm{M}\right)$. Excellent activity could be observed for angustine (2), nauclefine (4), and naucletine (5) at the early stage within 10-30 min after injection of each sample (more than $90 \%$ relaxation at $1 \times 10^{-5} \mathrm{M}$ ), whereas naucline (1) showed a moderate vasorelaxant activity $\left(90 \%\right.$ relaxation at $\left.1 \times 10^{-5} \mathrm{M}\right)$ (Figure 4). Vasodilation by these indole alkaloids seems to be influenced by substitution of a nitrogen atom in ring E. In the previous paper, we have reported vasorelaxant activities of some bisbenzylisoquinoline alkaloids such as $\alpha^{\prime}$-oxoperakensimines A-C from Alseodaphne perakensis and A. corneri [25,26], and $\mathrm{N}$-allyllaurolitsine from Litsea lancifolia [27]. These vasorelaxant effects may be mediated through the increased release of NO from endothelial cells. The mode of action of these indole alkaloids 1, 2, 4 and 5 on vasorelaxant activity is under investigation.

Figure 4. Relaxation responses induced by naucline $\left(1 ; 1 \times 10^{-5} \mathrm{M}\right)$, angustine $\left(2 ; 1 \times 10^{-5} \mathrm{M}\right)$, nauclefine (parvine) $\left(4 ; 1 \times 10^{-5} \mathrm{M}\right)$, and naucletine $\left(5 ; 1 \times 10^{-5} \mathrm{M}\right)$ in aortic rings precontracted with $3 \times 10^{-4} \mathrm{M}$ phenylephrine $(\mathrm{PE})$.

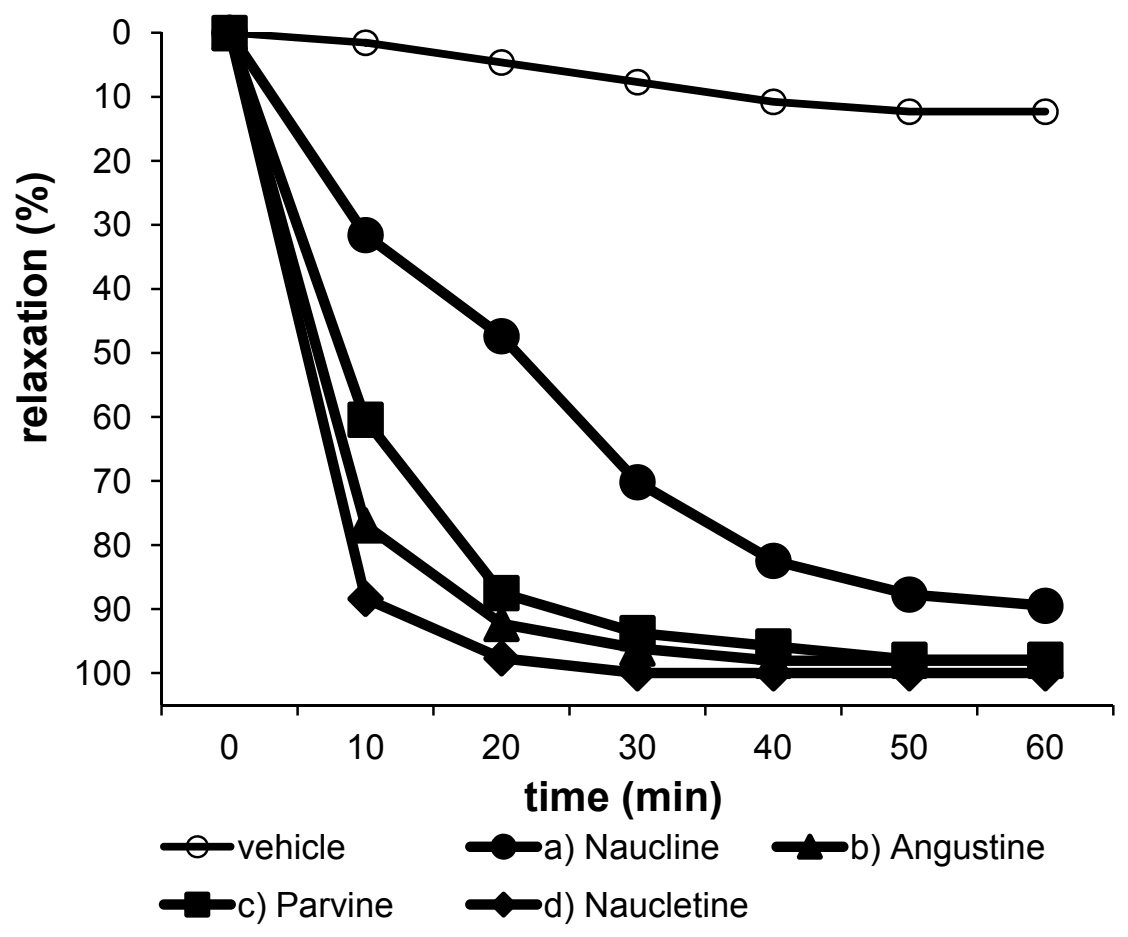

\section{Experimental}

\subsection{General Procedures}

Spectra were recorded on the following instruments: UV, Shimadzu UV-250 UV-visible spectrophotometer; IR, Perkin Elmer 1600; NMR, JEOL ECA 400 MHz; LCMS-IT-TOF, Shimadzu. All solvents, except those used for bulk extraction are AR grade. Silica gel $60 \mathrm{~F}_{254}$ for thin layer chromatography (TLC) was used for column chromatography. Glass and aluminum supported silica 
gel $60 \mathrm{~F}_{254}$ plates were used for TLC. TLC spots were visualized under UV light (254 and $365 \mathrm{~nm}$ ) followed by spraying with Dragendorff's reagent for alkaloid detection.

\subsection{Plant Material}

The bark of Nauclea officinalis was collected at Hutan Simpan Madek, Keluang, Johor, Malaysia by the phytochemical group of the Department of Chemistry, Faculty of Science, University of Malaya. The voucher specimen (KL 5655) of this plant has been deposited at the Herbarium of the Department of Chemistry, University of Malaya, Kuala Lumpur, Malaysia.

\subsection{Extraction and Isolation}

Dried, grounded bark of the plant $(2.0 \mathrm{~kg})$ was first defatted with hexane (17 litres) for one night. The dried materials then were extracted using $\mathrm{CH}_{2} \mathrm{Cl}_{2}$ (17 litres) twice for a 3-day period. The supernatant obtained was concentrated using rotary evaporator under reduced pressure to a volume of $500 \mathrm{~mL}$ and examined for its alkaloid content (using TLC and confirmed by spraying with Dragendorff's reagent). The extract was finally concentrated to give crude alkaloids $(11.0 \mathrm{~g})$. The crude alkaloid ( $8.0 \mathrm{~g}$ ) was subjected to column chromatography over silica gel using dichloromethane and methanol solvent (100:0, 99:1, 98:2, 97:3, 96:4, 95:5, 94:6, 90:10, 83:17, and 75:25) and finally with $100 \%$ methanol was used as eluent to obtain twenty fractions. Further purification of fraction 14 by Preparative Thin Layer Chromatography (PTLC) yielded alkaloid 1 (7.9 mg, $\mathrm{MeOH}-\mathrm{CH}_{2} \mathrm{Cl}_{2} ;$ 97:3: saturated with $\mathrm{NH}_{4} \mathrm{OH}$ ). Both known compounds 3 (1.5 mg, $\mathrm{MeOH}_{-} \mathrm{CH}_{2} \mathrm{Cl}_{2} ; 98: 2$ : saturated with $\mathrm{NH}_{4} \mathrm{OH}$ ) and 4 (7.2 mg, $\mathrm{MeOH}-\mathrm{CH}_{2} \mathrm{Cl}_{2} ; 98: 2$ : saturated with $\left.\mathrm{NH}_{4} \mathrm{OH}\right)$ were obtained after purification of fraction 12, while the compounds 2 (8.5 mg, $\mathrm{MeOH}-\mathrm{CH}_{2} \mathrm{Cl}_{2} ; 98: 2$ : saturated with $\left.\mathrm{NH}_{4} \mathrm{OH}\right)$ and 5 (10.1 $\mathrm{mg}$, $\mathrm{MeOH}-\mathrm{CH}_{2} \mathrm{Cl}_{2} ; 99: 1$ : saturated with $\mathrm{NH}_{4} \mathrm{OH}$ ) were obtained from fractions 7 and 6 , respectively.

Naucline (1)

Brown amorphous solid, LCMS-IT-TOF at $m / z 319.1450\left([\mathrm{M}+\mathrm{H}]^{+}\right.$for $\mathrm{C}_{20} \mathrm{H}_{18} \mathrm{~N}_{2} \mathrm{O}_{2}$; UV (MeOH) 374, $215 \mathrm{~nm}$; IR $\left(\mathrm{CHCl}_{3}\right) \lambda_{\max }: 3188,2924,2859,1639,1572,1533,1496$, and $1456 \mathrm{~cm}^{-1} ;{ }^{1} \mathrm{H}-$ and ${ }^{13} \mathrm{C}-\mathrm{NMR}$ : see Table 1.

\subsection{Vasodilation Assay}

A male Wistar rat weighing $260 \mathrm{~g}$ was sacrificed by bleeding from carotid arteries under anesthetization. A section of the thoracic aorta between the aortic arch and the diaphragm was removed and placed in oxygenated, modified Krebs-Henseleit solution (KHS: $118.0 \mathrm{mM} \mathrm{NaCl}$, $4.7 \mathrm{mM} \mathrm{KCl}, 25.0 \mathrm{mM} \mathrm{NaHCO}_{3}, 1.8 \mathrm{mM} \mathrm{CaCl}_{2}, 1.2 \mathrm{mM} \mathrm{NaH}_{2} \mathrm{PO}_{4}, 1.2 \mathrm{mM} \mathrm{MgSO}$, and $11.0 \mathrm{mM}$ glucose). The aorta was cleaned of loosely adhering fat and connective tissue and cut into ring preparations $3 \mathrm{~mm}$ in length. The tissue was placed in a well-oxygenated $\left(95 \% \mathrm{O}_{2}, 5 \% \mathrm{CO}_{2}\right)$ bath of $5 \mathrm{~mL}$ KHS solution at $37{ }^{\circ} \mathrm{C}$ with one end connected to a tissue holder and the other to a force-displacement transducer (Nihon Kohden, TB-611T). The tissue was equilibrated for $60 \mathrm{~min}$ under a resting tension of $1.0 \mathrm{~g}$. During this time the KHS in the tissue bath was replaced every $20 \mathrm{~min}$. 
After equilibration, each aortic ring was contracted by treatment with $3 \times 10^{-7} \mathrm{M}$ PE. The presence of functional endothelial cells was confirmed by demonstrating relaxation to $1 \times 10^{-5} \mathrm{M}$ acetylcholine (ACh), and aortic ring in which $80 \%$ relaxation occurred, were regarded as tissues with endothelium. When the PE-induced contraction reached a plateau, each sample $\left(\mathbf{1}, \mathbf{2}, \mathbf{4}\right.$ and $\left.\mathbf{5}, 1 \times 10^{-5} \mathrm{M}\right)$ was added.

These animal experimental studies were conducted in accordance with the Guiding Principles for the Care and Use of Laboratory Animals, Hoshi University and under the supervision of the Committee on Animal Research of Hoshi University, which is accredited by the Ministry of Education, Science, Sports Culture, and Technology of Japan.

\section{Conclusions}

In conclusion, five alkaloids were isolated from the bark of Nauclea officinalis of which one is a new pyranoindoloquinolizidinone alkaloid, which has been named naucline (1). The formation of 1 was proposed to ocurr as shown in Scheme 1. The biogenetic precursor of 1 would be naucleamide D which could undergo a dehydration involving the hydroxyl group at C-21 to form naucline (1). Naucline (1) showed a moderate vasorelaxant activity $\left(90 \%\right.$ relaxation at $\left.1 \times 10^{-5} \mathrm{M}\right)$ whereas angustine (2), nauclefine (4) and naucletine (5) showed excellent vasorelaxant activity (more than 90\% relaxation at $1 \times 10^{-5} \mathrm{M}$ ) on an isolated rat aorta.

Scheme 1. A proposed biogenesis process of naucleamide D to naucline (1).

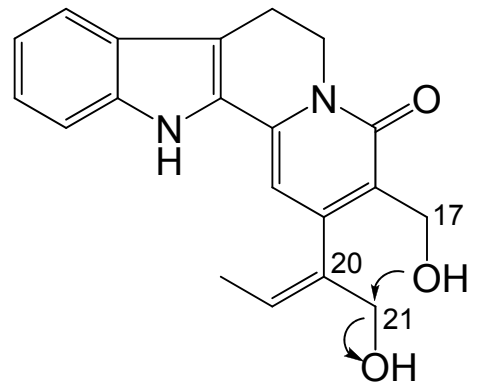

Naucleamide D

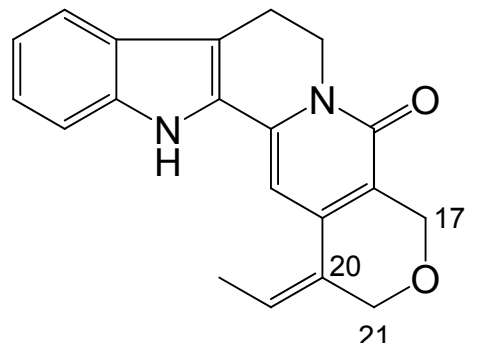

Naucline (1)

\section{Acknowledgements}

This work was supported by University Malaya Research grant, UMRG045/11BIO, Malaysia, Grant-in-Aid for Scientific Research from the Ministry of Education, Culture, Sports, Science, and Technology of Japan, and CNRS Grant, France. We also acknowledge the support given by Din Mohd Nor, Hasri Abdullah and Rafly Syamsir from the Herbarium Group, University of Malaya andTeo Leong Eng for plant identified. This work was carried out within the framework of an official agreement between the CNRS and the University of Malaya (Malaysia).

\section{References and Notes}

1. Rova, T.H.E.; Delprete, P.G.; Andersson, L.; Albert, V.A. A trnL-F cpDNA sequence study of the condamineeae-rondeletieae-sipaneeae complex with implications on the phylogeny of the rubiaceae. Am. J. Bot. 2002, 89, 145-159. 
2. Mongrand, S.; Badoc, A.; Patouille, B.; Lacomblez, C.; Chavent, M.; Bessoule, J.-J. Chemotaxonomy of Rubiaceae family based on leaf fatty acid composition. Phytochemistry 2005, 66, 549-559.

3. Shigemori, H.; Kagata, T.; Ishiyama, H.; Morah, F.; Ohsaki, A.; Kobayashi, J. Naucleamides A-E, new monoterpene indole alkaloid from Nauclea latifolia. Chem. Pharm. Bull. 2003, 51, 58-61.

4. Burn, E.N.; Taiwe, G.S.; Moto, F.C.O.; Ngoupaye, G.T.; Nkantchoua, G.C.N.; Pelanken, M.M.; Rakotonirina, S.V.; Rakotonirina, A. Anticonvulsant, anxioloytic, and sedative propertives of the roots of Nauclea latifolia Smith in mice. Epilepsy Behav. 2009, 15, 434-440.

5. Okoro, I.O.; Osagie, A.; Asibor, E.O. Antioxidant and antimicrobial activities of polyphenols from ethanomedicinal plants of Nigeria. Afr. J. Biotechnol. 2010, 9, 2989-2993.

6. Sichaem, J.; Surapinit, S.; Siripong, P.; Khumkratok, S.; Jong-aramruang, J.; Tip-pyang, S. Two new cytotoxic isomeric indole alkaloids from the roots of Nauclea orientalis. Fitoterapia 2010, $81,830-833$.

7. Takayama, H.; Tsutsumi, S.; Kitajima, M.; Santiarworn, D.; Liawruangrath, B.; Aimi, N. Glucoindole alkaloids from Nauclea cadamba in thailand and transformation of $3 \alpha$-dihydrocadambine into the indolopyridine alkaloid, 16-carbomethoxynaufoline. Chem. Pharm. Bull. 2003, 51, 232-233.

8. Zhang, Z.; ElSohly, H.N.; Jacob, M.R.; Pasco, D.S.; Walker, L.A.; Clark, A.M. New indole alkaloid from the bark of Nauclea orientalis. J. Nat. Prod. 2001, 64, 1001-1005.

9. Sun, J.Y.; Lou, H.X.; Xu, H.; Dai, S.J.; Liu, K. Two new indole alkaloids from Nauclea officinalis. Chin. Chem. Lett. 2007, 18, 1084-1086.

10. Sun, J.Y.; Lou, H.X.; Dai, S.J.; Xu, H.; Zhao, F.; Liu, K. Indole alkaloids from Nauclea officinalis with antimalarial activity. Phytochemistry 2008, 69, 1405-1410.

11. Qureshi, A.K.; Mukhtar, M.R.; Hirasawa, Y.; Hosoya, T.; Nugroho, A.E.; Morita, H.; Shirota, O.; Mohamad, K.; A. Hadi, A.H.; Litaudon, M.; Awang, K. Neolamarckines A and B, new indole alkaloids from neolamarckia cadamba. Chem. Pharm. Bull. 2011, 59, 291-293.

12. Abreu, P.; Pereira, A. New indole alkaloids from Sarcocephalus Latifolius. Nat. Prod. Lett. 2001, $15,43-48$.

13. Au, T.Y.; Cheung, H.T.; Sternhell, S. New corynanthe alkaloids from Strychnos angustiflora. J. Chem. Soc. Perkin Trans. I 1973, 1, 13-16.

14. Batchily, F.; Mehri, H.; Plat, M.; Sevenet, T. Alkaloids from Neisosperma kilneri (F.V.Mueller) Fosberg et Sachet. Ann. Pharm. Fr. 1985, 43, 513-520.

15. Hotellier, F.; Delaveau, P.; Poisset, J.-L. Nauclefine and naucletine, two new indoloquinolizidine alkaloids isolated from Nauclea Latifolia. Phytochemistry 1975, 14, 1407-1409.

16. Massiot, G.; Thepenier, P.; Jacquier, M.-J.; Men-Oliver, L.L.; Verpoorte, R.; Delaude, C. Alkaloids of Strychnos Johnsonii. Phytochemistry 1987, 26, 2839-2846.

17. Phillipson, J.D.; Hemingway, S.R. Angustine and related alkaloids from species of Mitragyna, Nauclea, Uncaria, and Strychnos. Phytochemistry 1974, 13, 973-978.

18. Solis, P.N.; Wright, C.W.; Gupta, M.P.; Phillipson, J.D. Alkaloids from Cephaelis Dichroa. Phytochemistry 1993, 33, 1117-1119.

19. Abreu, P.; Pereira, A. New indole alkaloids from Sarcocephalus Latifolius. Heterocycles 1998, 48, 885-891.

20. Sainsbury, M.; Webb, B. Parvine, a new Angustine-type alkaloid from Nauclea Parva. Phytochemistry 1975, 14, 2601-2603. 
21. Zeches, M.; Richard, B.; Gueye-M'Bahia, L.; Le Men-Olivier, L.; Delaude, C. Constituents of root bark of Nauclea pobeguinii. J. Nat. Prod. 1985, 48, 42-46.

22. Van De Santos, L.; Fett-Neto, A.G.; Kerber, V.A.; Elisabetsky, E.; Quirion, J.-C.; Henriques, A.T. Indole monoterpene alkaloids from leaves of Psychotria suterella Müll. Arg. (Rubiaceae). Biochem. Syst. Ecol. 2001, 29, 1185-1187.

23. Lavilla, R.; Gullón, F.; Bosch, J. Regioselective syntheses of the indolopyridine alkaloid nauclefine, angustine, dihydroangustine and naucletine from a common intermediate. $J$. Chem. Soc. Chem. Commun. 1995, 16, 1675-1676.

24. Morita, H.; Iizuka, T.; Choo, C.-Y.; Chan, K.-L.; Takeya, K.; Kobayashi, J. Vasorelaxant activity of cyclic peptide, cyclosquamosin B, from Annona squamosa. Bioorg. Med. Chem. Lett. 2006, 16, 4609-4611.

25. Mukhtar, M.R.; Nafiah, M.A.; Awang, K.; Thomas, N.F.; Zaima, K.; Morita, H.; Litaudon, M.; A. Hadi, A.H. $\alpha^{\prime}$-Oxoperakensimines A-C, new bisbenzylisoquinoline alkaloids from Alseodaphne perakensis (Gamble) Kosterm. Heterocycles 2009, 78, 2085-2092.

26. Mukhtar, M.R.; Zahari, A.; Nafiah, M.A.; A. Hadi, A.H.; Thomas, N.F.; Arai, H.; Morita, H.; Litaudon, M.; Awang, K. 3',4'-Dihydronorstephasubine, a new bisbenzylisoquinoline from the bark of Alseodaphne corneri. Heterocycles 2009, 78, 2571-2578.

27. Sulaiman, S.N.; Mukhtar, M.R.; A. Hadi, A.H.; Awang, K.; Hazni, H.; Zahari, A.; Litaudon, M.; Zaima, K.; Morita, H. Lancifoliaine, a new bisbenzylisoquinoline from the bark of Litsea lancifolia. Molecules 2011, 16, 3119-3127.

Sample Availability: Not available.

(C) 2012 by the authors; licensee MDPI, Basel, Switzerland. This article is an open access article distributed under the terms and conditions of the Creative Commons Attribution license (http://creativecommons.org/licenses/by/3.0/). 